P-ISSN 2442-6636

E-ISSN 2355-3987

www.ijhn.ub.ac.id

Artikel Hasil Penelitian

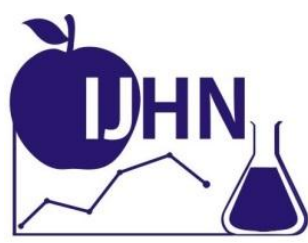

\title{
Hubungan Tingkat Kecukupan Energi, Protein, Kalsium, dan Fosfor dengan Panjang Tungkai Remaja
}

\author{
Anggitiya Ulfi Fadhilah ${ }^{1}$, Agus Sartono ${ }^{1 *}$, Hapsari Sulistya Kusuma ${ }^{1}$ \\ Program Studi SI Ilmu Gizi Fakultas Ilmu Keperawatan dan Kesehatan \\ Universitas Muhammadiyah Semarang. \\ *Alamat korespondensi: Asartono15@yahoo.com
}

Diterima: 24 Maret 2017 Direview: 20 Juni $2017 \quad$ Dimuat: Juni 2017

\begin{abstract}
Abstrak
Tungkai adalah ekstremitas bawah sebagai penopang tubuh bagian atas dan terdiri dari beberapa tulang. Pola konsumsi makanan, terutama sumber energi, protein, kalsium, dan fosfor, pada remaja merupakan faktor yang dapat memengaruhi pertumbuhan tungkai. Studi pendahuluan di SMP Walisongo 1 Semarang menunjukkan 10 dari 18 siswa (usia 14 tahun) memiliki tinggi badan tidak sesuai umurnya. Penelitian ini bertujuan untuk mengetahui hubungan antara tingkat kecukupan energi, protein, kalsium, dan fosfor dengan panjang tungkai remaja di SMP Walisongo 1 Semarang. Rancangan penelitian ini adalah cross sectional. Jumlah sampel sebanyak 38 siswa, yang ditetapkan secara purposive sampling. Data konsumsi diukur dengan metode recall 3 x 24 jam. Panjang tungkai diukur menggunakan pita ukur. Hubungan variabel diuji dengan Kolerasi Pearson dan Regresi Linier Berganda. Hasil penelitian menunjukkan bahwa 63,2\% remaja kekurangan energi, 34,2\% kekurangan protein, 97,4\% kekurangan kalsium, dan 60,6\% kekurangan fosfor. Tidak ada hubungan antara tingkat kecukupan energi dengan panjang tungkai $(p=0,176)$, tingkat kecukupan protein dengan panjang tungkai $(p=0,150)$, tingkat kecukupan kalsium dengan panjang tungkai $(p=0,840)$, dan tingkat kecukupan fosfor dengan panjang tungkai $(p=0,295)$. Kesimpulan penelitian ini adalah tingkat kecukupan energi, protein, kalsium, dan fosfor tidak berhubungan dengan panjang tungkai pada remaja SMP Walisongo 1 Semarang.
\end{abstract}

Kata kunci: energi, protein, kalsium, fosfor, panjang tungkai remaja

\begin{abstract}
Limb is the lower extremity as upper body support and consists of several bones. The pattern of food consumption, especially energy, protein, calcium, and phosphorus sources, in adolescents is a factor affecting the limb growth. A preliminary study at Walisongo Junior High School 1 Semarang showed 10 out of 18 students (aged 14 years old) had inappropriate height. This study aims to determine the correlation among adequacy of energy, protein, calcium, and phosphorus with the limb length among adolescents in Walisongo Junior High School 1 Semarang. This study used cross sectional design research. The number of samples was 38 students determined by purposive sampling. The consumption was measured by $3 \times 24$ hour recall method. Limb length was measured using measuring tape. Variable relationships were tested using Pearson Correlation and Multiple Linear Regression. The results showed that $63.2 \%$ of adolescents lack of energy, $34.2 \%$ protein deficiency, $97.4 \%$ calcium deficiency, and $60.6 \%$ phosphorus deficiency. There was no correlation between energy sufficiency level with limb length $(p=0.176)$, protein adequacy level with limb length
\end{abstract}


( $p=0.150)$, calcium adequacy level with limb length ( $p=0.840)$, and phosphorus adequacy level with limb length ( $p=0.295)$. This research concludes that the sufficiency level of energy, protein, calcium, and phosphorus does not relate to limb length of the adolescent in Walisongo Junior High school 1 Semarang.

Keywords: energy, protein, calcium, phosphorus, adolescent's limb length

\section{PENDAHULUAN}

Manusia tumbuh dan kembang sejak bayi sampai dewasa. Pertumbuhan akan berhenti pada saat kita dewasa, tetapi perkembangan akan terus berlanjut sampai kita berusia tua [1]. Pertumbuhan cepat akan tejadi pada periode usia bayi baru lahir sampai usia 2 tahun, usia 6-8 tahun, dan puncak percepatannya akan terjadi pada usia 13-15 tahun yang disebut sebagai pacu tumbuh kembang adolesen [2].

Pada periode pacu tumbuh kembang remaja, perubahan fisik, biokimia, dan emosional akan terjadi dengan cepat. Pada periode inilah terjadi puncak pertumbuhan tinggi badan dan berat badan. Kecepatan pertambahan tinggi badan pada laki-laki akan mencapai $20 \mathrm{~cm}$ per tahun dan pada perempuan $16 \mathrm{~cm}$ per tahun [3]. Salah satu bentuk pertumbuhan tinggi badan adalah memanjangnya tungkai [4]. Pertumbuhan tinggi badan akan berhenti pada usia 18-23 tahun, yang disebabkan oleh terjadinya penulangan atau penutupan episfisis [5].

Pertumbuhan yang optimal, terutama memanjangnya tulang, membutuhkan asupan energi, protein, kalsium, dan fosfor dalam jumlah yang cukup [6]. Pada masa pacu tumbuh kembang adolesen, kebutuhan protein akan mencapai 44-59 gram [2]. Kebutuhan fosfor dan kalsium akan meningkat karena pada masa ini pertumbuhan tinggi badan dan pembentukan massa tulang berlangsung dengan cepat [5]. Fosfor dan kalsium merupakan elemen-elemen penting pembentuk tulang, khususnya dalam proses mineralisasi tulang. Densitas tulang, ukuran tulang, dan tinggi badan dapat dijadikan sebagai indikator kualitas pertumbuhan dan pembentukan tulang $[7,8]$.

Hasil penelitian Nainggolan (2012), di SDN 173438 Balige menunjukkan bahwa tinggi badan berhubungan dengan kecukupan protein dan kalsium dari susu, tetapi tidak berhubungan dengan kecukupan protein dan kalsium dari makanan lain. Penelitian Hardinsyah (2007) menunjukkan konsumsi kalsium tidak berhubungan dengan densitas tulang dan tinggi badan. Tetapi jumlah konsumsi susu dan frekuensi minum susu berhubungan dengan tinggi badan dan densitas tulang $[6,8]$.

Studi pendahuluan di SMP Walisongo 1 Semarang menunjukkan tinggi badan 10 dari 18 siswa yang berusia 14 tahun, tidak sesuai kriteria tinggi badan dalam AKG sehingga tergolong pendek. Ditemukan 4 siswa yang memiliki tinggi badan yang sama tetapi panjang tungkainya berbeda. Temuan inilah yang membuat peneliti tertarik melakukan penelitian yang bertujuan untuk mengetahui hubungan antara tingkat kecukupan energi, protein, kalsium, dan fosfor dengan panjang tungkai pada remaja di SMP Walisongo 1 Semarang.

\section{METODE PENELITIAN \\ Rancangan/Desain Penelitian}

Penelitian ini adalah observasional analitik dengan rancangan penelitian.

\section{Sumber Data}

Siswa yang menjadi sampel dan lembaga pendidikan SMP Walisongo I Semarang.

\section{Sasaran Penelitian}

Sampel yang sekaligus menjadi responden penelitian berjumlah 38 siswa SMP Walisongo 1 Semarang yang terdiri dari 17 siswa perempuan $(44,7 \%)$ yang umur 12 tahun dan 21 siswa 1aki-laki $(55,3 \%)$ yang berumur 14 tahun. Pengam- 
bilan sampel menggunakan teknik purposive sampling.

\section{Pengembangan Instrumen dan Teknik Pengumpulan Data}

Data karakteristik responden diukur dengan metode wawancara Konsumsi energi, protein, kalsium dan fosfor diukur dengan metode recal $3 \times 24$ jam, tak berurutan. Panjang tungkai diukur dengan menggunakan pita ukur. Data pedukung/ sekunder diperoleh dari catatan/dokumentasi yang ada di SMP Walisongo 1 Semarang.

\section{Teknik Analisis Data}

Analisis univariat dilakukan dengan menggunakan Mean (nilai rata-rata hitung), standar deviasi (SD) dan tabel distribusi frekuensi. Kenormalan distribusi data diuji dengan 1 uji Kolmogorov Smirnov-Z, yang hasilnya menunjukkan semua data variabel berdistribusi normal. Uji statistik hubungan variabel yang digunakan adalah uji korelasi Pearson dan uji regresi linier berganda.

\section{HASIL}

\section{Karakteristik Responden}

Responden penelitian adalah 38 siswa kelas VII sampai dengan kelas IX SMP Walisongo 1 Semarang, yang terdiri dari 17 siswa perempuan $(44,7 \%)$ yang umur 12 tahun dan 21 siswa 1aki-laki $(55,3 \%)$ yang berumur 14 tahun.

\section{Hubungan Tingkat Kecukupan Energi dengan Panjang Tungkai}

Hasil uji korelasi Pearson menunjukkan tidak ada hubungan tingkat kecukupan energi dengan panjang tungkai $(\mathrm{p}=0,176$ dan $\mathrm{r}=0,224)$. Hasil uji korelasi Pearson menunjukkan bahwa tidak ada hubungan tingkat kecukupan energi dengan panjang tungkai siswa perempuan $(\mathrm{p}=0,065$ dan $\mathrm{r}=0,457)$. Hasil uji korelasi Pearson menunjukkan bahwa tidak ada hubungan antara tingkat kecukupan energi dengan panjang tungkai pada siswa laki-laki ( $p=0,693$ dan $r=0,092$ ).

\section{Hubungan Tingkat Kecukupan Protein dengan Panjang Tungkai}

Hasil uji korelasi Pearson menunjukkan bahwa tidak ada hubungan antara tingkat kecukupan protein dengan panjang tungkai $(\mathrm{p}=0,150$ dan $\mathrm{r}=-0,238)$.

Hasil uji korelasi Pearson menunjukkan tidak ada hubungan antara tingkat kecukupan protein dengan panjang tungkai siswa perempuan $(\mathrm{p}=0,107$ dan $\mathrm{r}=0,405)$. Hasil uji korelasi Pearson menunjukkan tidak ada hubungan antara tingkat kecukupan protein dengan panjang tungkai siswa laki-laki ( $\mathrm{p}=0,483$ dan $\mathrm{r}=0,162)$.

\section{Hubungan Tingkat Kecukupan Kalsium dengan Panjang Tungkai}

Hasil uji korelasi Pearson menunjukkan tidak ada hubungan antara tingkat kecukupan kalsium dengan panjang tungkai ( $\mathrm{p}=0,840$ dan $\mathrm{r}=0,034$ ). Hasil uji korelasi Pearson menunjukkan tidak ada hubungan antara tingkat kecukupan kalsium dengan panjang tungkai siswa perempuan $(\mathrm{p}=0,971$ dan $\mathrm{r}=0,010)$. Hasil uji korelasi Pearson menunjukkan tidak ada hubungan antara tingkat kecukupan kalsium dengan panjang tungkai siswa laki-laki $(\mathrm{p}=0,634$ dan $r=0,110$ ).

\section{Hubungan Tingkat Kecukupan Fosfor dengan Panjang Tungkai}

Hasil uji korelasi Pearson menunjukkan tidak ada hubungan antara tingkat kecukupan fosfor dengan panjang tungkai ( $\mathrm{p}=0,295$ dan $\mathrm{r}=0,174)$. Hasil uji korelasi Pearson menunjukkan tidak ada hubungan antara tingkat kecukupan fosfor dengan panjang tungkai siswa perempuan ( $\mathrm{p}=0,487$ dan $\mathrm{r}=0,181$ ). Hasil uji korelasi Pearson menunjukkan tidak ada hubungan antara tingkat kecukupan fosfor siswa lakilaki ( $\mathrm{p}=0,759$ dan $\mathrm{r}=0,071)$.

Hasil analisis bivariat yang dilakukan menunjukkan bahwa variabel yang dapat 
dianalisis dengan regresi linier berganda adalah tingkat kecukupan energi dan protein secara keseluruhan (gabungan lakilaki dan perempuan) dan pada hanya pada perempuan (memenuhi syarat $\mathrm{p}=0,25$ ). Hasil uji linier berganda dapat dilihat pada Tabel 1.

Tabel 1. Hasil Akhir Uji Regresi Linier Berganda pada Data secara Keseluruhan

\begin{tabular}{lcc}
\hline \multicolumn{1}{c}{ Variabel Independen } & Sig. & Beta \\
\hline Tingkat Kecukupan Energi & 0,819 & $-0,074$ \\
Tingkat Kecukupan Protein & 0,588 & $-0,175$ \\
\hline
\end{tabular}

Tabel 2. Hasil Akhir Uji Regresi Linier Berganda pada Perempuan

\begin{tabular}{lcc}
\hline \multicolumn{1}{c}{ Variabel Independen } & Sig. & Beta \\
\hline Tingkat Kecukupan Energi & 0,332 & $-0,344$ \\
Tingkat Kecukupan Protein & 0,656 & $-0,156$ \\
\hline
\end{tabular}

Hasil uji regresi berganda menunjukkan bahwa secara keseluruhan pengaruh tingkat kecukupan energi terhadap panjang tungkai adalah $7,4 \%$, sedangkan pada perempuan pengaruh tingkat kecukupan energi terhadap panjang tungkai sebesar $34,4 \%$. Secara keseluruhan, pengaruh tingkat kecukupan protein terhadap panjang tungkai adalah $17,5 \%$, sedangkan pada perempuan adalah $15,6 \%$.

\section{PEMBAHASAN}

\section{Hubungan Tingkat Kecukupan Energi dengan Panjang Tungkai}

Hasil penelitian ini menunjukkan bahwa tidak ada hubungan antara tingkat kecukupan energi dengan panjang tungkai. Hasil penelitian ini sama dengan hasil penelitian Nainggolan (2012), menunjukkan tidak terdapat hubungan yang bermakna antara kecukupan energi dengan tinggi badan anak. Hasil penelitian ini juga sama dengan hasil penelitian Suciati (2008) pada anak usia 4-6 tahun di TK AlHusna Bekasi, yang menunjukkan tidak ada hubungan antara sumbangan energi sehari dari makanan sumber kalsium dengan status gizi berdasarkan TB/U [9].

\section{Hubungan Tingkat Kecukupan Protein dengan Panjang Tungkai}

Hasil penelitian menunjukkan bahwa tidak ada hubungan antara tingkat ke- cukupan protein dengan panjang tungkai. Pengaruh protein terhadap pertumbuhan berkaitan dengan banyaknya hormon pertumbuhan yang disintesis oleh protein, sehingga semakin banyak hormon pertumbuhan yang disintesis oleh protein maka pertumbuhan tinggi badan akan berlangsung baik [6]. Pada penelitian ini, banyaknya hormon pertumbuhan yang disintesis tidak bisa dikendalikan.

Faktor lain penyebab tidak adanya hubungan tingkat kecukupan protein dan panjang tungkai adalah bahwa panjang tungkai dan tinggi badan adalah indikator pertumbuhan linier yang merupakan refleksi asupan gizi masa lalu dan bukan masa sekarang [6]. Pada peneliti ini, faktor genetik belum dikontrol sehingga sangat mungkin menjadi variabel pengganggu. Proses instruksi genetik yang terkandung di dalam sel telur akan menghasilkan kualitas dan kuantitas pertumbuhan [2].

Hasil penelitian ini berbeda dengan peneiltian Nainggolan (2012) yang menunjukkan tingkat kecukupan protein dari konsumsi makanan berhubungan dengan tinggi badan anak dengan menggunakan adalah uji chi-square $p=0,000$. Hasil penelitian Sukartini (2012) juga berbeda dengan penelitian ini. Penelitian Sukartini dengan responden anak usia 5-7 tahun di Kelurahan Kampung Melayu Jakarta Timur menunjukkan bahwa ada hubungan 
yang bermakna antara kecukupan asupan protein dengan indeks $\mathrm{TB} / \mathrm{U}(p=0,037)$ [10].

\section{Hubungan Tingkat Kecukupan Kalsium dengan Panjang Tungkai}

Hasil penelitian ini menunjukkan tidak ada hubungan antara tingkat kecukupan kalsium dengan panjang tungkai. Hasil penelitian ini sejalan dengan hasil penelitian Nainggolan (2012), yang menunjukan tidak terdapatnya hubungan antara konsumsi kalsium dari pangan nonsusu dengan tinggi badan dan densitas tulang. Hal ini dapat terjadi karena konsumsi kalsium dari non-susu hanya merupakan sebagian dari asupan total kalsium harian. Pangan sumber kalsium seperti tahu, tempe, kacang-kacangan, dan sayuran hijau mengandung serat dan oksalat yang akan membentuk garam tidak larut, sehingga menghambat absorpsi kalsium dalam tubuh. Kondisi ini akan menyebabkan tidak efektifnya kandungan kalsium yang tinggi dalam asupan bahan makanan yang dikonsumsi [11].

Menurut Holman (1987) dalam Hardinsyah (2007), remaja yang berusia kurang dari 19 tahun membutuhkan sekitar empat cangkir (0,9 liter) susu sehari untuk memenuhi kebutuhan kalsiumnya. Massa tulang rangka perempuan lebih kecil dibandingkan dengan laki-laki, sehingga absorpsi kalsium pada laki-laki lebih tinggi dibandingkan dengan perempuan . Selain itu, densitas tulang yang lebih besar pada remaja laki-laki diduga karena remaja lakilaki lebih sering melakukan olahraga secara teratur dibandingkan remaja perempuan [8].

Kebutuhan gizi kelompok usia remaja relatif tinggi karena pada usia remaja terjadi pertumbuhan yang cepat disertai perubahan fisiologis sehingga dibutuhkan pengaturan gizi yang tepat meliputi jumlah, jenis, dan frekuensinya makanan. Kebutuhan gizi erat kaitannya dengan masa pertumbuhan. Pertumbuhan akan optimal apabila asupan zat gizi terpenuhi.
Selain itu, remaja pada umumnya melakukan aktifitas yang lebih banyak sehingga membutuhkan energi, protein, vitamin dan mineral seperti kalsium lebih banyak dari orang dewasa karena di perlukan untuk pembentukan jaringan dan pertumbuhan tulang otot [12].

\section{Hubungan Tingkat Kecukupan Fosfor dengan Panjang Tungkai}

Hasil penelitian ini menunjukkan tidak ada hubungan antara tingkat kecukupan fosfor dengan panjang tungkai. Dilihat dari hasil food recall, asupan fosfor masih kurang disebabkan oleh jarang mengonsumsi makanan sumber fosfor yang berasal dari kacang-kacangan, ikan, susu dan hasil olahannya. Jajanan mereka di sekolah juga tidak banyak menyumbangkan kalsium, contohnya minuman kemasan, minuman bersoda dan chiki. Hal ini juga dapat disebabkan oleh faktor responden lupa atau tidak jujur dalam mengungkapkan apa yang dikonsumsi ketika diwawancarai. Keterbatasan peneliti dalam hal kecermatan saat melakukan recall dapat juga berpengaruh terhadap vaiditas data yang diperoleh.

Faktor lain penyebab tidak adanya hubungan tingkat kecukupan protein dan panjang tungkai, adalah bahwa panjang tungkai dan tinggi badan adalah indikator pertumbuhan linier yang merupakan refleksi asupan gizi masa lalu dan bukan masa sekarang [6]. Pada peneliti ini, faktor genetik belum dikontrol sehingga sangat mungkin menjadi variabel pengganggu. Proses intruksi genetik yang terkandung didalam sel telur akan menghasilkan kualitas dan kuantitas pertumbuhan [2].

\section{SIMPULAN}

Rata-rata panjang tungkai remaja murid SMP Walisongo adalah $81,52 \mathrm{~cm} \pm$ $7,08 \mathrm{~cm}$. Sebagian besar remaja $(63,2 \%)$ mengalami kekurangan energi, 34,2\% mengalami kekurangan protein hampir seluruhnya $(97,4 \%)$ mengalami kekurangan kalsium, dan 60,6\% mengalami ke- 
kurangan fosfor. Tidak terdapat hubungan antara tingkat kecukupan energi, protein, kalsium, dan fosfor dengan panjang tungkai.

\section{DAFTAR PUSTAKA}

1. Soetjiningsih. Tumbuh Kembang Anak. Jakarta: EGC; 2004.

2. Adriani dan Bambang. Pengantar Gizi Masyarakat. Jakarta: Kencana; 2012.

3. Achadi L.E. Gizi dan Kesehatan Masyarakat. Departemen Gizi dan Kesehatan Masyarakat Fakultas Kesehatan Masyarakat, Universitas Indonesia. Edisi I. Jakarta: PT. Raja Grafindo Persada; 2007.

4. Sorongan C.H., Rumampuk J.L.F. Hubungan Panjang Tungkai dengan Kecepatan Berjalan pada Siswa Sekolah Menengah Atas Negeri 6. Manado: Universitas Sam Ratulangi; 2012.

5. Devi N. Gizi Anak Sekolah. Jakarta: Kompas; 2012.

6. Nainggolan R.S., Aritonang E.Y., Ardiani F. Hubungan Pola Konsumsi Makanan dan Konsumsi Susu dengan Tinggi Badan Anak Usia 6-12 tahun di SDN 173538 Balige. Jurnal Gizi, Kesehatan Reproduksi dan Epidemiologi. 2014; 1(3):1-8.

7. Ramayulis R., Pramantara I.D.P., Pangastuti R., Asupan Vitamin,
Mineral, Rasio Asupan Kalsium dan Fosfor dan Hubunganya dengan Kepadatan Mineral Tulang Kalkaneus Wanita. Jurnal Gizi Klinik Indonesia. 2011; 7(3):129-136.

8. Hardinsyah, Damayanthi E., Zulianti W. Hubungan Konsumsi Susu dan Kalsium dengan Densitas Tilang dan Tinggi Badan Remaja. Semiloka Nasional Prospek Industri Sapi Perah Menuju Perdagangan Bebas 2020. 2008; 247-254.

9. Suciati L. Hubungan Pengetahuan Ibu tentang Kalsium dan Frekuensi Konsumsi Kalsium serta Asupanya dengan Status Gizi Anak 4-6 Tahun di TK AL-Husna Bekasi. Tidak dipublikasikan. Depok: Universitas Indonesia; 2008.

10. Regar E., Sekartini R. Hubungan Kecukupan Energi dan Makronutrien dengan Status Gizi Anak Usia 5-7 Tahun di Keluharan Kampung Melayu, Jakarta Timur. eJKI. 2013; 1( 3):184-189.

11. Almatisier S. Prinsip Dasar Ilmu Gizi. Jakarta: PT Gramedia; 2009.

12. Haq A.B. Status Gizi, Asupan Makan pada Remaja Putri yang Berprofesi sebagai Model. Tidak dipublikasikan. Semarang: Universitas Diponegoro; 2014. 